Federal Reserve Bank of Dallas

Globalization and Monetary Policy Institute

Working Paper No. 42

http://www.dallasfed.org/assets/documents/institute/wpapers/2010/0042.pdf

\title{
Size and Composition of the Central Bank Balance Sheet: Revisiting Japan's Experience of the Quantitative Easing Policy ${ }^{*}$
}

\author{
Shigenori Shiratsuka \\ Institute for Monetary and Economic Studies \\ Bank of Japan \\ January 2010
}

\begin{abstract}
This paper re-examines Japan's experience of the quantitative easing policy in light of the policy responses against the current financial and economic crisis. Central banks use various unconventional measures in the range of financial assets being purchased and in the scale of such purchases. As the scope of such unconventional measures expands, it is often emphasized that the U.S. Federal Reserve policy reactions focus more on the asset side of its balance sheet, the so-called credit easing. By contrast, the Bank of Japan's quantitative easing policy from 2001 to 2006 set a target for the current account balances, the liability side of its balance sheet. It is crucial to understand that central banks combine the two elements of their balance sheets, size and composition, to enhance the overall effects of unconventional policy measures, given constraints on policy implementation.
\end{abstract}

JEL codes: E44, E52, E58

\footnotetext{
* Shigenori Shiratsuka, 2-1-1 Nihonbashi-Hongokucho, Chuo-ku, Tokyo 103-8660, Japan. +81-(0)33277-3076. shigenori.shiratsuka@boj.or.jp. I benefited from the discussions with Shin-ichi Fukuda, Takatoshi Ito, Ken Kuttner, Philippe Moutot, Erlend W. Nier, Kunio Okina, Huw Pill, Giovanni Vitale, Tsutomu Watanabe, the staffers of the Bank of Japan, and participants of the 2009 WEAI Annual Meeting in Vancouver and the workshop at the Ministry of Finance. I also thank Hiroyuki Ooi and Jouchi Nakajima for their assistance. The views expressed in the paper are mine and do not necessarily reflect those of the Bank of Japan, the Federal Reserve Bank of Dallas or the Federal Reserve System.
} 


\section{Introduction}

This paper re-examines Japan's experience of the quantitative easing policy (QEP) in light of policy responses to the current financial and economic crisis in the major economies. ${ }^{1}$ This paper thereby attempts to provide a roadmap for a more comprehensive understanding of the unconventional monetary policy.

Confronted with the current financial and economic crisis, central banks have moved swiftly and aggressively to counter the adverse effects of the malfunctioning financial system. In that process, central banks have implemented policy measures mainly in three main areas: reducing the policy interest rate, securing the stability of financial markets, and facilitating corporate financing. In the second and third areas, central banks in the major economies have introduced various unconventional measures in the range of financial assets being purchased and in the scale of such purchases (Table 1). ${ }^{2}$ As a result, central banks in major economies have expanded their balance sheets significantly, especially after the collapse of Lehman Brothers in September 2008 (Figure 1).

The U.S. Federal Reserve (Fed) has dramatically expanded its balance sheet through "credit easing" measures designed to intervene aggressively in the credit products market and related markets. The Bank of England (BOE) has established a program for outright purchase of gilts and corporate bonds (CBs) to boost the supply of money and to improve the functioning of corporate credit markets. ${ }^{3}$ The European Central Bank (ECB) has extended its regular refinancing operations to "fixed-rate fullallotment" liquidity provisions with a longer maturity up to 12 months. It has also introduced a purchasing program for covered bonds. ${ }^{4}$ The Bank of Japan (BOJ) has

1 For the lessons from Japan's experience since the burst of the bubble in the early 1990s, see also a series of speeches by Shirakawa (2009a, c, e).

2 As private financial intermediation restores its normal function, some of the unconventional measures are currently scheduled to be terminated in due course. For example, the Fed announced that it would complete its purchases of agency debt and agency mortgage-backed securities by the end of the first quarter of 2010.

3 The BOE uses the term of "quantitative easing" to describe its unconventional policy measures. For the outline of its policy framework, see the BOE's pamphlet, entitled Quantitative Easing Explained (http://www.bankofengland.co.uk/monetarypolicy/pdf/qe-pamphlet.pdf).

4 The ECB termed its unconventional policy measures as "enhanced credit support." See, for example, Trichet (2009a, b). 
introduced various measures to ensure the stability in financial markets as well as to facilitate corporate financing, including fixed-rate full-allotment liquidity provisions against eligible corporate debts. The BOJ has also resumed the purchase of stocks held by financial institutions and introduced a scheme to provide subordinated loans to financial institutions. ${ }^{5}$

The aforementioned policy reactions by major central banks give the impression of diverse approaches to support the economy. As central banks in the major economies expand their scope of unconventional policy measures, it is often emphasized that the Fed's policy reactions put more emphasis on the asset side of the central bank balance sheet, termed credit easing. ${ }^{6}$ Such policy responses often contrast with the BOJ's QEP from 2001 to 2006, setting a target for the current account balances, the liability side of its balance sheet.

The distinct difference arises not because central banks have different objectives, but because they face different environments and restrictions, such as the types and origins of the shocks hitting the economy, the structure of the financial system, and institutional arrangements of the central bank. When viewing from a broad perspective, the responses of various central banks demonstrate more similarities than differences.

Looking back at the BOJ's policy responses after the burst of the bubble, especially since the late 1990s, we can find the striking similarities to the policy

5 For more detailed information of the BOJ's policy measures in the current financial crisis, see the special web page of the BOJ's web site (http://www.boj.or.jp/en/type/exp/seisaku_cfc/index.htm). In implementing various unconventional measures, the BOJ has emphasized the importance of acting as a safety valve for the financial system, given that the financial condition of Japanese financial institutions has been relatively stable even after the emergence of the U.S. subprime mortgage problem. Regarding the stability of Japan's financial system, BOJ (2009) concluded that "Japan's financial system has generally been stable, although the effects from the global financial crisis that began in 2008 still remain."

6 Bernanke (2009a) first termed the Fed's approach to supporting credit markets as credit easing, and pointed out the conceptual distinction from the QEP, carried out by the BOJ from 2001 to 2006. Yellen (2009) also pointed out that "the differences outweigh the similarities" by comparing the current Fed's practice and the BOJ's experience, pointing the Fed's focus on the asset side of its balance sheet to improve credit flows in specific markets. In that context, Bean (2009) mentioned that the BOE's quantitative easing was differentiated from the BOJ's QEP by designing its asset purchase program to target the assets held primarily by the non-bank private sector. 
measures currently taken by central banks in the major economies. ${ }^{7}$ The BOJ provided ample excess reserves by using various tools for money market operations, including an increase in the outright purchase of long-term government bonds. The BOJ also adopted credit easing measures in the current terminology. The assets purchased included asset-backed securities (ABSs) and asset-backed commercial papers (ABCPs). The BOJ also took unprecedented measures to secure the stability of the financial system, including the purchases of stocks held by financial institutions.

In theory, such unconventional monetary policy can be implemented by combining the two elements of the central bank balance sheet, size and composition. The size corresponds to expanding the balance sheet, while keeping its composition unchanged (narrowly-defined quantitative easing). The composition corresponds to changing the composition of the balance sheet, while keeping its size unchanged by replacing conventional assets with unconventional assets (narrowly-defined credit easing).

In a financial and economic crisis, both the asset and liability sides of the central bank balance sheet play an important role in countering the adverse effects stemming from the financial system. The asset side works as a substitute for private financial intermediation, for example, through the outright purchase of credit products. The liability side, especially expanded excess reserves, functions as a buffer for funding liquidity risk in the money markets. In addition, the two sides interact closely, since malfunctions in financial intermediation are closely tied to funding liquidity risk at financial institutions, resulting in the increased demand for excess reserves.

In practice, given constraints on policy implementation, central banks have combined the two elements of their balance sheet, size and composition, to enhance the overall effects of unconventional policy. In that respect, quantitative easing, often used in a vague manner, better fits as a package of unconventional policy measures making use of both the asset and liability sides of the central bank balance sheet, designed to absorb the shocks hitting the economy (broadly-defined quantitative easing).

7 Shirakawa (2009a, c) also points out the striking similarities between the policy measures taken by the BOJ since the late 1990s and those currently taken by central banks in the major economies. We also find some differences at the same time, especially in the employment of a policy commitment. The BOJ made a commitment to the QEP "until core CPI inflation becomes stably zero or above." In the current crisis, however, quite a few central banks, such as the Bank of Canada and Sveriges Riksbank, have employed policy commitment. 
The BOJ's QEP from 2001 to 2006 can be viewed as broadly-defined quantitative easing, as the policy responses of central banks to the current financial and economic crisis.

Such a way of understanding about unconventional policy measures suggests a close connection with a policy commitment regarding the duration for maintaining short-term interest rates at virtually zero, since financial and economic circumstances that require unconventional policy measures are most likely to accompany an extremely low level of policy interest rates for a considerable period into the future. In that sense, it is inappropriate to consider that unconventional policy measures and policy commitment under zero interest rates are completely separated policy measures.

This paper is organized as follows. Section II summarizes Japan's experience of the quantitative easing policy from 2001 to 2006. Section III examines the role of the central bank balance sheet under unconventional monetary policy, by focusing on the link between the two sides of the balance sheet. Section IV provides concluding remarks.

\section{BOJ's Quantitative Easing Policy from 2001 to 2006}

This section reviews Japan's experience of the QEP and summarizes its effects mainly on financial markets (See Table 2 for the major policy events under the QEP).

\section{A. Basic Framework of BOJ's Quantitative Easing Policy}

On March 19, 2001, The BOJ adopted a new monetary easing framework of the QEP in response to an economic downturn triggered by the burst of the global IT bubble. The QEP consisted of three pillars:

(1) The BOJ changed its main operating target for money market operations from the uncollateralized overnight call rate to the outstanding balance of the current account balances (CABs) held by financial institutions at the BOJ.

(2) The BOJ committed itself to maintaining the above procedure until the core CPI (headline excluding perishables) inflation became stably zero or above. ${ }^{8}$ 
(3) The BOJ would increase the amount at the outright purchase of long-term Japanese government bonds (JGBs), up to a ceiling of the outstanding balance of banknotes issued, if judged necessary to ensure the smooth provision of liquidity.

The QEP started with a CAB target at 5 trillion yen, a level slightly above the required reserve level of 4 trillion yen (Figure 2). The target was then progressively increased in response to the decline in economic activity. The target was finally raised to 30-35 trillion yen in January 2004, and remained unchanged at that level until the QEP was terminated in March 2006.

Reflecting the ample liquidity provision under the QEP, the uncollateralized overnight call rate fell to 0.001 percent, a level below the $0.02-0.03$ percent in place from 1999 to 2000 under the zero interest rate policy (ZIRP). To meet the CAB target smoothly, the BOJ gradually increased the outright purchase of long-term JGBs from the initial pace of 400 billion yen per month, setting the amount at 1,200 billion yen per month beginning in October 2002. From July 2003 to March 2006, as a temporary measure, the BOJ purchased ABSs with a view toward supporting the development of the ABS market and strengthening the transmission mechanism of monetary policy.

The core CPI inflation turned positive in November 2005, and the rate for January 2006, announced in early March, was 0.5 percent (Figure 3). ${ }^{9}$ On March 9, 2006, the BOJ deemed the conditions for the commitment under the QEP met and decided to terminate the QEP and to return the operating target of money market operations to the uncollateralized overnight call rate, while maintaining the rate at effectively zero percent.

When terminating the QEP, the BOJ announced that the CABs would be reduced over a period of a several months, fully taking into account conditions in the short-term money market. The reductions in the CABs proceeded smoothly as

only that the most recently published core CPI should register a zero or above, but also that such tendency should be confirmed over a few months. Second, the Bank needs to be convinced that the prospective core CPI will not be expected to fall below zero.

9 The year on year changes in the CPI revised downward by 0.43 percentage points at the time of 2005 base revision, which was a far larger downward revision, compared with the previous 2000 base year revision of 0.25 percentage points. 
scheduled in a few months before the first policy rate increase in July 2006. ${ }^{10}$ The BOJ's communication efforts to convey its policy intention played a key role in several respects. First, the conditions for the commitment to the QEP enhanced the predictability of the timing of the termination of the QEP. Second, in the face of market expectations regarding the termination of the QEP, the BOJ repeatedly explained that the termination itself would entail no sudden policy changes and that the policy rates would be adjusted only gradually. Third, the BOJ encouraged financial institutions to prepare for a decline in excess reserves by re-establishing the management system for funding liquidity risk. ${ }^{11}$

\section{B. Effects of the BOJ's Quantitative Easing Policy}

This subsection summarizes the effects of the QEP by focusing on financial markets, since empirical evidence suggests that the expansion of the monetary base had limited effects on aggregate variables, such as output and inflation. Ugai (2007) concludes in his comprehensive survey on empirical studies on the effects of the QEP, that effect of expanding the monetary base and altering the composition of the BOJ's balance sheet, if any, is generally smaller than that stemming from the policy commitment. ${ }^{12}$

Given the fragile state of the financial markets, the ample provision of reserves under the QEP, coupled with the policy commitment of maintaining zero interest rates for a considerable period into the future, resulted in the strong liquidity effect. Okina and Shiratsuka (2004a) empirically examined the effects of policy commitment on the market expectations, implied in the changes in the shape of yield curves, the so-called

10 As a basis for the smooth exit from the QEP, restoration of the stability in Japan's financial system is crucial. In fact, the blanket protection on bank deposits was lifted without confusion in April 2005.

11 In this connection, the maturity of the short-term fund-supplying operation shortened in advance to the termination of the QEP, from the second half of 2005. That was because the BOJ tried to minimize the intervention to the money markets, thereby promoting restoration of their functioning, including smoother formation of interest rates on term transactions.

12 In that context, Ito and Mishkin (2006), for example, argued that the BOJ's policy responses were not aggressive enough to fight deflation, and, in addition, that lack of the BOJ's confidence on the effectiveness of unconventional policy measures did undermine their effects. By contrast, Ueda (2005) recollected that major misconceptions about the BOJ's policy measures arose in the outside of the BOJ, including academic economists, leading to bold arguments for using extreme measures to overcome deflationary economic conditions, without recognizing the similarity of the BOJ's policy measures under the ZIRP and the QEP with policy measures advocated by academic economists. 
policy duration effect. They showed that the policy duration effect was highly effective in stabilizing market expectations regarding the future path of short-term interest rates, thereby bringing longer-term interest rates down to flatten the yield curve. ${ }^{13}$ They also concluded that the policy duration effect failed to reverse deflationary expectations in financial markets, since monetary policy alone could not reverse deflation, coupled with low economic growth.

The term spread, defined as the difference between the term contracts of Japanese yen Tokyo interbank offered rates (TIBOR) and the overnight call rate, declined significantly (Figure 4). In that context, the maturity of short-term fundssupplying operation does matter as an element in changes in the composition of the central bank balance sheet. During the QEP, the maturity of money market operations lengthened for the smooth provision of ample liquidity, running for ten months in billpurchase operations at the final stage of the QEP (Figure 5). In that sense, the BOJ's QEP was carried out by implementing short-term funds-supplying operations in a flexible manner in terms of both instrument and maturity, thereby producing the significant effect of mitigating liquidity risk.

Note that the liquidity effect is likely to differ, depending on the conditions of the financial system. ${ }^{14}$ In fact, we can see a more significant decline in the term spread after the introduction of the zero interest rate policy in February 1999. Before then, Japanese financial institutions as a whole confronted severe credit constraints, and a significant liquidity event occurred virtually every business day. ${ }^{15}$

13 Oda and Ueda (2007) carried out a counterfactual simulation, based on their estimated macrofinance model, and showed that the policy commitment under the ZIRP and the QEP stabilized market expectations regarding the future course of short-term interest rates at a low level, thus pushing down the yield curve.

14 Fujiki and Shiratsuka (2002) empirically examined the liquidity effects of the ZIRP in Japan from 1999 to 2000. They showed that the zero interest rate policy, even with a restricted expansion of the reserves, produced a very significant liquidity effect under a very fragile condition of the Japanese money market.

15 In the late 1990s, Japanese financial institutions faced more serious liquidity constraints in dollar funding, as shown in, for example, Saito and Shiratsuka (2001). In this context, currency swap agreements between central banks contributed significantly to mitigating liquidity constraints in dollar funding under the current financial crisis. 
Additionally, the QEP influenced credit spreads significantly (Figure 6). ${ }^{16}$ The credit spread for financial institutions, measured as the difference between the CD rate and the TB rate in three-month contracts, appears to have declined sharply soon after the introduction of the QEP. The credit spreads for non-financial businesses, measured as the differences between the credit products indicators across ratings and the TB rate in three-month contracts, also declined, but with certain time-lags after the introduction of the QEP, indicating a significant reduction in the external financing premium for the non-financial business sector. It should be noted that such significant reductions in the external financing premium was realized by lesser amounts of direct intervention in credit products markets (Figure 7).

As examined so far, the QEP played a certain role in bolstering Japan's economy, in particular by stabilizing the financial system. Such stimulative effects failed to be transmitted to the outside of the financial system, suggesting that the transmission channel between the financial and non-financial sectors had been blocked. ${ }^{17}$ The QEP did not thus produce the effect of reversing the financial market's expectations that deflation would persist, as discussed in Okina and Shiratsuka (2004a).

At the same time, the QEP produced certain side-effects particularly coming from pushing short-term interest rates down to virtually zero, evidenced as a deterioration in the functioning of the money markets. ${ }^{18}$ That is clearly visible in the sharp decline in the outstanding amounts of the uncollateralized call market: from around 20 trillion yen in early 2001 to 3.4 trillion yen in December 2002 (Figure 8). Such declined outstanding amounts of the uncollateralized call market did not recover in 2004-05 even after Japan's financial system restored its stability as a whole, with resolving the nonperforming loan problem.

16 See, for example, Baba et al. (2006) for empirical evidence of reduction in credit spreads for Japanese financial institutions in money markets.

17 Okina and Shiratsuka (2004b) pointed out that the BOJ had to conduct monetary policy under a significant and unforeseen slowdown in the potential growth, which differed significantly from a standard stabilization policy around a stable growth trend. Under such circumstances, it should be stressed that the elimination of the structural impediments themselves is a more effective policy response than measures taken for a sustained period to offset cyclical factors.

18 There seems to be a general consensus among the central banks that money market rates are need to keep at a positive level to minimize the side effects arising from a zero-interest-rate environment. 
Under the QEP, market participants lost the incentive to engage in transactions in the call market. Lenders barely covered transaction costs, given very tight interest margins, since the overnight call rate remained very close to zero. Borrowers did not need to raise funds in the money market primarily because the funds-supplying operations of the BOJ offered the primary means of financing. That implies that the money markets under zero interest rates with ample liquidity almost stopped functioning as a risk-sharing device among financial institutions. Financial institutions chose the face-to-face transactions with the BOJ, in preference to market transactions with other participants.

\section{Unconventional Monetary Policy}

This section examines the role of the central bank balance sheets under unconventional monetary policy, focusing on the link between the two sides of the balance sheet.

\section{A. Typology of Unconventional Monetary Policies}

The policy responses of central banks to the current financial and economic crisis can be divided into three main areas: reducing the policy interest rate; securing the stability of financial markets; and facilitating corporate financing. In the second and third areas, central banks in the major economies have introduced various unconventional measures in the range of financial assets being purchased and in the scale of such purchases. Central banks have implemented such unconventional measures by aggressively changing the size and composition of their balance sheets.

As central banks in the major economies expand the scope of unconventional policy measures, it is often emphasized that the Fed's policy reactions put more emphasis on the asset side of the central bank balance sheet, an approach referred to as credit easing. For example, Bernanke (2009a) first called the Fed's approach to supporting credit market as credit easing, and points out the conceptual distinction from the QEP undertaken by the BOJ from 2001 to 2006. He argued that the stimulative effects of credit easing depend crucially on the particular mix of lending programs and securities purchases tailored to the dysfunctional credit markets in the United States. ${ }^{19}$

19 Bernanke (2009a) also mentioned that the differences in approach between the Fed and the BOJ do 
In theory, such unconventional policy can be decomposed into two elements (Figure 9): The first element focuses on the size of the central bank balance sheet, while the second element focuses on the composition of the central bank balance sheet. In the hypothetical case, the first element can be implemented by increasing the balance sheet size while keeping its composition unchanged by restraining money market operations with standard tools (narrowly-defined quantitative easing). The second element can be implemented by changing the composition of the balance sheet while keeping its size unchanged by replacing conventional assets with unconventional assets (narrowly-defined credit easing).

Bernanke and Reinhart (2004) used the above classification of unconventional monetary policy and provide an overview of monetary policy strategies when short-term interest rates are very low or even zero. ${ }^{20}$ They examined the effects of changing the composition and size of the central bank balance sheet, in addition to altering market expectations about the future course of short-term interest rates. They focused primarily on the portfolio rebalancing effect stemming from the changes in the composition and size of the central bank balance sheet. By shifting the composition of asset holdings from shorter- to longer-dated government securities, a central bank may influence term premiums and an overall yield curve, if investors treat them as imperfect substitutes. Similarly, by increasing the monetary base, a central bank may also influence prices and yields of non-money assets, if the monetary base is an imperfect substitute for other financial assets.

In the policy responses to the current financial and economic crisis, however, both the asset and liability sides of the central bank balance sheet play roles different from the above portfolio rebalancing effects. ${ }^{21}$ On the one hand, the asset side works as a substitute for private financial intermediation, for example, through outright purchases of credit products. On the other hand, the liability side, especially expanded excess reserves, functions as a buffer for liquidity risk in the financial markets. In

not reflect "any doctrinal disagreement," but "rather the differences in financial and economic conditions between the two episodes."

20 Bernanke, Reinhart, and Sack (2004) provided a comprehensive review on empirical evidence of monetary policy alternatives at the zero lower bound of nominal interest rates.

21 One of the important factors in formulating an exit strategy from unconventional policy measures is whether an expansion of the central bank balance sheet is driven by its asset side or liability side. I will come back to this point in the next subsection. 
addition, the two sides interact closely with each other, since malfunctions in financial intermediation are closely tied to funding liquidity risk at financial institutions, resulting in the increased demand for excess reserves.

In practice, central banks have attempted to combine the two elements of their balance sheet, size and composition, to enhance the overall effects of unconventional monetary policy based on their specific environments and restrictions, such as types and origins of the shocks hitting the economy, the structure of the financial system, and institutional arrangements of the central bank. In that regard, quantitative easing fits better as a package of unconventional policy measures to absorb the shocks hitting the economy, given the constraints on their policy implementation (broadly-defined quantitative easing). The BOJ's QEP from 2001 to 2006 can be viewed as broadlydefined quantitative easing, as the policy responses of central banks to the current financial and economic crisis.

\section{B. Determinants of Size and Composition}

As described by the typology of unconventional monetary policies, central banks implement unconventional monetary policy by changing both the size and composition of their balance sheets. In this case, the size and composition of the balance sheet depends on the state of the economy, particularly the financial system.

For example, when the increases in balance sheet size come from increased demand for excess reserves due to serious concern over liquidity risk, not the malfunctions in financial intermediation, but the increases in conventional money market operations may accommodate an expansion of the balance sheet. In this case, such conventional operations are implemented by extending their maturity, as the case seen in the BOJ's QEP (see Figure 5). That can be seen as kind of credit easing in the maturity variety, not in the product variety. Conversely, when not excess reserve demand, but the malfunctions in financial intermediation induce an expansion of the central bank balance sheet, increased purchases of unconventional financial assets should be accommodated by increases in some sort of central bank liability.

Figure 10 shows the balance sheets for the BOJ and the Fed. The figure shows that the increases on the liability side are mostly attributable to the increases in reserves, while currency in circulation, a major liability in normal times, remains relatively stable. 
By contrast, the sources of increases on the asset side significantly differ between the BOJ and the Fed. The BOJ increases both JGB holdings and other conventional assets. ${ }^{22}$ The Fed increases not only short-term lending, but also central bank liquidity swaps, credit facilities, and agency mortgage backed securities. In short, the BOJ and the Fed accommodate increased demand for reserves to mitigate liquidity risk by purchasing different types of assets.

The differences in assets purchased are closely related to the differences in the financial structure of the economy. ${ }^{23}$ Figure 11 illustrates the structures of financial intermediation in Japan and the United States. The figure clearly shows that Japan has a largely bank-centered financial system, while the United States has a primarily market-based financial system.

The U.S. financial system, particularly the credit products markets closely linked to the subprime mortgages, has fallen into serious dislocation. In response, the Fed has naturally taken credit-easing measures to intervene aggressively in the credit products markets and related markets, seeking temporarily to serve in place of the malfunctioning private financial intermediation using its own balance sheet. In addition, such malfunctions in the credit products markets are closely tied to funding liquidity risk at financial institutions, resulting in the accumulation of excess reserves, which appears on the liability side of the Fed's balance sheet.

\section{Balance Sheet Expansion and Zero Interest Rates}

As mentioned above, Bernanke and Reinhart (2004) consider two types of the policy options under zero lower bound constraints of nominal interest rates: changing the composition and size of the central bank balance sheet as well as altering market expectations about the future course of short-term interest rates. In the current crisis, however, only a limited number of central banks have employed an explicit policy

\footnotetext{
22 In addition, the BOJ introduced the purchases of stocks held by financial institutions, since market risk associated with stock-holdings was the major risk component for Japanese banks, especially major banks. For the details on the costs-benefits analysis of equity holdings of Japanese banks, see Chapter IV of BOJ (2007).

23 Trichet (2009) pointed out that the ECB's policy actions are at all times carefully calibrated to the structure of the euro economy and its financial structure in particular.
} 
commitment. 24 In this case, what do we think of the relationship between unconventional monetary policy and policy commitment under zero nominal interest rates?

Focusing on the expectation channel, a central bank can produce further easing effects by a policy commitment, even when short-term interest rates decline to virtually zero. $^{25}$ A central bank can influence market expectations by making an explicit commitment to the duration for which it will hold short-term interest rates at virtually zero. If it succeeds in credibly extending its commitment duration, it can reduce longer-term interest rates. ${ }^{26}$

As mentioned earlier, however, many central banks have employed unconventional policy measures without making a clear commitment to the future path of monetary policy in the current crisis. Unconventional policy measures are implemented through expanding the central bank balance sheet, and, during that process, policy interest rates are also reduced. It should be noted that policy interest rates are maintained marginally above zero, while policy interest rates are reduced to virtually zero during the ZIRP and the QEP. In the mean time, many central banks have adopted an interest payment scheme for excess reserves, thus coming to an understanding that it is unnecessary to guide the policy interest rates around virtually zero in maintaining a certain amount of excess reserves. ${ }^{27}$

24 Some central banks have employed some kinds of policy commitment to make clear their policy intention to stabilize longer-term interest rates. For example, the Bank of Canada has recently committed itself to maintaining its target overnight rate at 25 basis points for a full year, based on their inflation projections. In a weaker form of policy commitment, the Fed has been using kind of forwardlooking language: "[The committee] continues to anticipate that economic conditions are likely to warrant an exceptionally low level of the federal funds rates for an extended period."

25 See Reifschneider and Williams (2000), Jung, Teranishi, and Watanabe (2005), and Eggertsson and Woodford (2003) for detailed discussions on the policy commitment effect when a central bank faces the zero boundary of nominal interest rates.

26 We call this mechanism the "policy-duration effect," after Fujiki, Okina, and Shiratsuka (2001) and Fujiki and Shiratsuka (2002).

27 Once private financial intermediation restores normal functions, interest payments on reserves close to policy interest rates entail a risk of distorting resource allocation through the financial system. Thus, spreads between policy interest rates and interest rates for reserves are likely to expand gradually, thus promoting a reduction in excess reserves. That point is important, especially in relation to the exit strategy I will touch on later. 
In general, a central bank expands its balance sheet to deal with the worsening of the financial intermediation function and the increase in funding liquidity risk, associated with downward pressure on economic activity. Under such circumstances, monetary policy is principally directed towards reducing the policy interest rates, thereby easing monetary conditions. In particular, it is supposed that a central bank attempts to maintain the policy interest rate at an extremely low level when it expands its balance sheet on a large scale to deal with the tremendous adverse shocks stemming from the financial system. Therefore, since financial and economic circumstances that require unconventional policy measures are most likely to accompany an extremely low level of policy interest rates. In that sense, it is inappropriate to consider that unconventional policy measures and policy commitment under zero interest rates are completely separated policy measures.

Note that central banks' policy responses in the current crisis are not a natural extension of pure monetary policy under zero interest rates, but an emergency operation to rescue the financial system. In the current crisis, given the expansion of marketbased financial intermediation, many central banks have extended the scope of such rescue operations beyond the traditional role as lender of last resort, such as provision of funding liquidity to non-bank financial institutions and restoration of market liquidity in credit products and related markets. ${ }^{28}$

\section{Discussions}

Given the understanding of unconventional monetary policy discussed so far, this section addresses some questions at stake regarding the implementation of unconventional monetary policy.

\section{A. Nature of Balance Sheet Expansion}

Several policy implications arise from the above arguments on the determinants of size

28 Kuttner (2008), for example, viewed the recent Fed's policy responses as lender of last resort, and their effects and costs in detail. In addition, Tucker (2009) discussed three types of last resort operations in a financial crisis: lender of last resort, market maker of last resort, and capital of last resort. He pointed out that the first two operations are carried out by a central bank, while the last one needs to be done by a government. 
and composition of the central bank balance sheet.

First, quantitative easing is a package of unconventional policy measures making use of the both the asset and liability sides of the central bank balance sheet designed to absorb the shocks hitting the economy. A central bank attempts to combine the size expansion and the composition change to enhance the overall effects of unconventional monetary policy. That is a common characteristic to the BOJ's QEP from 2001 to 2006 and the policy responses of central banks to the current financial and economic crisis.

Second, quantitative easing is a temporary policy response. ${ }^{29}$ The increase in size and the change in composition of the central bank balance sheet simply buy time until certain progress will be made in balance sheet adjustments at financial institutions, such as disposal of non-performing assets and recapitalization. The increase in size and the change in composition of the central bank balance sheet do not directly lead to the early restoration of the financial intermediation function.

Third, quantitative easing is likely to produce side-effects, as a consequence of the strong policy measures implemented to stabilize the financial system. A massive expansion of the central bank balance sheet is the corollary of public intervention in private financial transactions, potentially distorting incentives and resource allocation in the private sector. In particular, such side-effects become more obvious as the duration of quantitative easing prolongs. In that sense, a cost-benefit comparison of unconventional monetary policy depends crucially on the length of time for which such massive intervention is needed.

\section{B. Permanent Portion as a Price Level Determinant}

While balance sheet expansion is a temporary policy response, the permanent portion of the expansion does matter with regard to the effects on general prices in the longer term. ${ }^{30}$ To avoid the adverse effects on general prices, any expansion of the balance

29 From a long-term perspective, it is important to explore a comprehensive policy framework for a central bank that encompasses policy management in normal times and crisis management. Such a framework needs to integrate monetary policy and prudential policy to achieve macroeconomic stability, comprised of price stability and financial system stability, as a basis for sound development of the economy. For the further discussions on that point, see Shirakawa (2009b, d, e).

30 In that context, Auerbach and Obstfeld (2005) discuss the effects of the central bank balance sheet 
sheet must be confined to sustainable levels in the medium to long term, even though an extraordinary expansion is allowed temporarily to absorb the shocks hitting the economy. ${ }^{31}$ In that context, it is crucial to stave off public concern that expanding the central bank balance sheet will result in money-financing of government deficit, thereby preventing instability in the government bond market.

In that regard, outright purchases of long-term government bonds play an important role. The BOJ has prudently implemented outright purchases of JGBs, as a long-term stable asset for the central bank, based on the need for money market operations to smoothly provide long-term stable funds according to the banknote demand. When introducing the QEP, the BOJ established a ceiling for outright purchases of long-term JGBs within the outstanding amount of bank note issuance (the so-called "banknote rule"). That rule makes it clear that the BOJ has no intention of providing price support for JGBs or money-financing of government deficit, thereby securing the credibility of the monetary policy.

\section{Balance Sheet Reduction in an Exit Strategy}

In formulating an exit strategy, a central bank needs to consider how to reduce its balance sheet as the financial system restores its stability over time.

Once private financial intermediation restores its normal function, a prolonged high level of central bank intervention to the financial system entails a risk of distorting resource allocation through the financial system. Thus, central bank intervention to the financial system is no longer necessary, and a central bank is unlikely to face any serious obstacle in reducing its balance sheet. ${ }^{32}$ By contrast, a central bank is unlikely

expansion through the fiscal channel. When the private sector recognizes that the monetary base will permanently increase by massive purchases of long-term government bonds by a central bank, the private sector comes to expect government debt interest payments to decline over time, consequently reducing the private sector's tax burden. In that case, massive inflation is required to achieve high nominal growth after the economy returns to normal with positive interest rates, while maintaining a permanent increase in the monetary base.

31 In that context, it seems a bit surprising that no economist argues that expansion of the central bank balance sheet is crucial in combating deflation in the current situation. Many economists used to advocate that the BOJ should expand its balance sheet as much as possible to combat deflation under zero nominal interest rates, because both deflation and inflation are monetary phenomena.

32 Nishimura (2009) argued that unconventional policy measures needed to possess a self-fading 
to exit from unconventional policy in a smooth manner with malfunctions in financial intermediation. Early economic recovery is hardly possible under such circumstances, given the interaction between the real and financial sectors of the economy.

Suppose that a central bank needs to reduce its balance sheet, since, for example, demand for excess reserves subsides, reflecting the recovery of the financial system functions, while a large amount of unconventional assets remains on the asset side of the central bank balance sheet. In particular, such a situation is likely to become prolonged, if the maturity of unconventional assets is long. In that process, a central bank is nevertheless able to control the size of its balance sheet by employing debt instruments to absorb excess liquidity from financial markets, including reverse repos, in addition to interest payments to excess reserves. ${ }^{33}$

Conversely, suppose that a central bank needs to raise short-term interest rates, while very high demand for excess reserves still exists at financial institutions. That implies that reserves and money markets transactions are still imperfect substitutes for each other. Money markets have yet to restore their normal function as a risk-sharing device among financial institutions. In that case, transactions in money markets remain highly restricted, and money market rates easily become volatile. Given such fragile conditions in money markets, a central bank is likely to face difficulty in guiding money market rates smoothly in a consistent manner to the targeted level of policy interest rates. In addition, a central bank may need to raise short-term interest rates on a larger scale, since the transmission mechanism linking financial and non-financial sectors remain blocked.

The above case is most likely to occur when a central bank is forced to raise short-term interest rates in view of the economy's risk of falling into stagflation. It is certainly critical for a central bank to maintain the credibility of monetary policy under

characteristic, by designing those measures to unwind themselves as market function improve. Trichet (2009c) also emphasized that the ECB's unconventional policy measures were designed with exit consideration in mind, and that a number of measures would phase out naturally.

33 Bernanke (2009c) argued that the Fed would be able to reduce its balance sheet in a smooth manner with interest payments to reserves, combined with the steps to reduce excess reserves, such as large-scale repurchasing agreements, term deposits to financial institutions, and the outright sale of its holdings of long-term securities. See also Dudley (2009) for further discussions on the Fed's money market operation to reduce its balance sheet. 
such a difficult situation. ${ }^{34}$ In fact, some argue that a central bank will be able to exit from very low interest rate conditions without reducing its balance sheet size, since a central bank has effective tools for controlling short-term interest rates, including payment of interest on reserves. In that case, a central bank needs to control shortterm interest rates by making use of interest payments on reserves, while maintaining a certain size of its balance sheet. It should be noted, however, that a considerable degree of uncertainty remains regarding the transmission mechanism from short-term interest rates to medium- to long-term interest rates, asset prices, and general prices and economic activity.

\section{Concluding Remarks}

This paper has attempted to provide a roadmap for a better and more comprehensive understanding of unconventional monetary policy by re-examining Japan's experience of the QEP in light of the policy responses to the current financial and economic crisis in major economies. It is crucial to understand that unconventional monetary policy in reality combines the two sides of the central bank balance sheet, size and composition, to enhance the overall effects of unconventional policy to absorb the shocks hitting the economy, given the constraints on policy implementation.

\section{References}

Auerbach, Alan J., and Maurice Obstfeld, "The Case for Open-Market Purchases in a Liquidity Trap," American Economic Review, 95(1), 2005, pp. 110-137.

Baba, Naohiko, Motoharu Nakashima, Yosuke Shigemi, and Kazuo Ueda, "The Bank of Japan's Monetary Policy and Bank Risk Premiums in the Money Market," International Journal of Central Banking, 2 (1), 2006, pp. 105-135.

Bank of Japan, Financial System Report, September 2007. Financial System Report, September 2009.

Bean, Charles, “Quantitative Easing: An Interim Report," Speech to the London Society of Chartered Accountants, October 13, 2009.

34 See, for example, Goodfriend (2009), and Bernanke (2009b). 
Bernanke, Ben S., "The Crisis and the Policy Response," Speech at the Stamp Lecture, London School of Economics, January 13, 2009a (http://www.federalreserve.gov/ newsevents/speech/berake20090113a.htm). , “The Fed's Exit Strategy,” Wall Street Journal, July 21, 2009b. , “The Federal Reserve's Balance Sheet: An Update," Speech at the Federal Reserve Board Conference on Key Developments in Monetary Policy, October 8, 2009c (http://www.federalreserve.gov/newsevents/speech/berake20091008a.htm). , and Vincent R. Reinhart, "Conducting Monetary Policy at Very Low Shortterm Interest Rates," American Economic Review, 94(2), 2004, pp. 85-90. , and Brian P. Sack, "Monetary Policy Alternatives at the Zero

Bound: An Empirical Assessment," Brookings Papers on Economic Activity 2, 2004, pp.1-78.

Dudley, William C., "The Economic Outlook and the Fed's Balance Sheet: The Issue of 'How' versus 'When'," Remarks at the Association for a Better New York Breakfast Meeting, July 29, 2009 (http://www.ny.frb.org/newsevents/speeches/ 2009/dud090729.html).

Eggertsson, Gauti, and Michael Woodford, "The Zero Bound on Interest Rates and Optimal Monetary Policy,” Brookings Papers on Economic Activity, 1, 2003, pp. $139-211$.

Fujiki, Hiroshi, Kunio Okina, and Shigenori Shiratsuka, "Monetary Policy under Zero Interest Rate: Viewpoints of Central Bank Economists," Monetary and Economic Studies, 19 (1), Institute for Monetary and Economic Studies, Bank of Japan, 2001, pp. 89-130. and Shigenori Shiratsuka, "Policy Duration Effect under the Zero Interest Rate Policy in 1999-2000: Evidence from Japan's Money Market Data," Monetary and Economic Studies, 20 (1), Institute for Monetary and Economic Studies, Bank of Japan, 2002, pp. 1-31.

Goodfriend, Marvin, "Central Banking in the Credit Turmoil: An Assessment of Federal Reserve Practice," Paper presented at the Bank of Japan 2009 International Conference, May 27-28, 2009.

Ito, Takatoshi, and Fredric S. Mishkin, “Two Decades of Japanese Monetary Policy and the Deflation Problem," Takatoshi Ito and Andrew Rose eds. Monetary Policy with Very Low Inflation in the Pacific Rim, The University of Chicago Press, 2006, 
pp.131-193.

Jung, Taehun, Yuki Teranishi, and Tsutomu Watanabe, "Optimal Monetary Policy at the Zero-Interest-Rate Bound," Journal of Money, Credit and Banking, 37 (5), 2005, pp. 813-835.

Kuttner, Kenneth N., "The Federal Reserve as Lender of Last Resort during the Panic of 2008," mimeo, 2008.

Nishimura, Kiyohiko G., "Unconventional Policies of Central Banks: Restoring Market Function and Confidence," Remarks at the Money and Banking Conference sponsored by the Central Bank of Argentina, September 1, 2009.

Oda, Nobuyuki, and Kazuo Ueda, “The Effects of the Bank of Japan's Zero Interest Rate Commitment and Quantitative Monetary Easing on the Yield Curve: A Macro-Finance Approach,” Japanese Economic Review, 58(3), 2007, pp. 303-328.

Okina, Kunio, and Shigenori Shiratsuka, "Policy Commitment and Expectation Formation: Japan's Experience under Zero Interest Rates," North American Journal of Economics and Finance, 15 (1), 2004a, pp. 75-100. , and , “Asset Price Fluctuations, Structural Adjustments, and Sustained Economic Growth: Lessons from Japan's Experience since the Late 1980s," Monetary and Economic Studies, 22 (S-1), 2004b, pp. 143-167.

Reifschneider, David, and John C. Williams, "Three Lessons for Monetary Policy in a Low-Inflation Era," Journal of Money, Credit and Banking, 32 (4), 2000, pp. 936966.

Saito, Makoto, and Shigenori Shiratsuka, "Financial Crises as the Failure of Arbitrage: Implications for Monetary Policy," Monetary and Economic Studies, 19 (S-1), Institute for Monetary and Economic Studies, Bank of Japan, 2001, pp. 239-276.

Shirakawa, Masaaki, "Way Out of Economic and Financial Crisis: Lessons and Policy Actions," Speech at Japan Society in New York, April 23, 2009a (http://www.boj.or.jp/en/type/press/koen07/ko0904c.htm).

, "Preventing the Next Crisis: The Nexus between Financial Markets, Financial Institutions and Central Banks," Speech at the London Stock Exchange, May 13, 2009b (http://www.boj.or.jp/en/type/press/koen07/ko0905b.htm).

, "Financial System and Monetary Policy Implementation: Long and Winding Evolution in the Way of Thinking," Opening Speech at 2009 International Conference hosted by the Institute for Monetary and Economic Studies, Bank of 
Japan, May 27, 2009c (http://www.boj.or.jp/en/type/press/koen07/ko0905e.htm). , "The Role of Central Banks in the New Financial Environment," Remarks at the International Monetary Conference in Kyoto on June 9, 2009d (http://www.boj.or.jp/en/type/press/koen07/ko0906b.htm) , "Some Thoughts on Incentives at Micro- and Macro-level for Crisis Prevention," Remarks at the Eighth Bank for International Settlements Annual Conference in Basel, Switzerland, June 26, 2009e (http://www.boj.or.jp/en/type/ press/koen07/ko0906e.htm)

, "Unconventional Monetary Policy -- Central Banks: Facing the Challenges and Learning the Lessons --," Remarks at the Conference co-hosted by the People's Bank of China and the Bank for International Settlements in Shanghai, August 8, $2009 \mathrm{f}$ (http://www.boj.or.jp /en/type/press/koen07/ko0908a.htm).

Tucker, Paul, "The Repertoire of Official Sector Interventions in the Financial System: Last Resort Lending, Market-making, and Capital," Remarks at 2009 Bank of Japan International Conference, May 28, 2009.

Trichet, Jean-Claude, "Supporting the Financial System and the Economy: Key ECB Policy Actions in the Crisis," Speech at a conference organized by the Nueva Economía Fórum and the Wall Street Journal Europe in Madrid, June 22, 2009a. , “The ECB's Enhanced Credit Support," Keynote address at the University of Munich, July 13, 2009b. , "The ECB's Exit Strategy," Speech at the ECB Watchers Conference, Frankfurt, September 4, 2009c.

Ueda, Kazuo, “The Bank of Japan's Struggle with the Zero Lower Bound on Nominal Interest Rates: Exercises in Expectations Management," International Finance, 8(2), 2005, pp. 329-350.

Ugai, Hiroshi, "Effects of the Quantitative Easing Policy: A Survey of Empirical Analyses," Monetary and Economic Studies, 25(1), Institute for Monetary and Economic Studies, 2007, Bank of Japan, pp. 1-47. 
Table 1. Policy Measures Taken by Major Central Banks

\begin{tabular}{|c|c|c|c|c|}
\hline & Bank of Japan & Federal Reserve & $\begin{array}{c}\text { European Central } \\
\text { Bank }\end{array}$ & Bank of England \\
\hline Rate cuts & $0.50 \%$ to $0.10 \%$ & $\begin{array}{c}2.00 \% \text { to } \\
0.00-0.25 \%\end{array}$ & $4.25 \%$ to $1.00 \%$ & $5.00 \%$ to $0.50 \%$ \\
\hline \multirow[t]{2}{*}{$\begin{array}{l}\text { Liquidity } \\
\text { provision }\end{array}$} & $\begin{array}{l}\text { - Sufficient } \\
\text { provision of funds } \\
\text { over calendar and } \\
\text { fiscal year-ends; } \\
\text { - Increase in } \\
\text { outright purchase } \\
\text { of JGBs; } \\
\text { - Interest on excess } \\
\text { reserve balances }\end{array}$ & $\begin{array}{l}\text { - Expansion of } \\
\text { TAF, PDCF, and } \\
\text { TSLF; } \\
\text { - Interest on reserve } \\
\text { balances }\end{array}$ & $\begin{array}{l}\text { - Fixed-rate full- } \\
\text { allotment liquidity } \\
\text { provision; } \\
\text { - Increase in } \\
\text { counterparties }\end{array}$ & $\begin{array}{l}\text { - Expansion of } \\
\text { long-term funds } \\
\text { provision } \\
\text { - Discount Window } \\
\text { Facility } \\
\text { - BoE Sterling bills } \\
\text { to drain reserves } \\
\text { - Operational } \\
\text { Standing Facility } \\
\text { - Interest on excess } \\
\text { reserve balances }\end{array}$ \\
\hline & - U.S. dollar repo & $\begin{array}{l}\text { - Increase in swap } \\
\text { lines with foreign } \\
\text { central banks }\end{array}$ & $\begin{array}{l}\text { - U.S. dollar repo } \\
\text { and Swiss franc } \\
\text { repo }\end{array}$ & - U.S. dollar repo \\
\hline \multirow[t]{2}{*}{ Others } & $\begin{array}{l}\text { - Increase in } \\
\text { frequency and size } \\
\text { of CP repo; } \\
\text { - Fixed-rate full- } \\
\text { allotment liquidity } \\
\text { provision against } \\
\text { eligible corporate } \\
\text { debt; } \\
\text { - Expansion of } \\
\text { eligible collateral }\end{array}$ & $\begin{array}{l}\text { - Supportive } \\
\text { measures against } \\
\text { individual problem } \\
\text { financial institution }\end{array}$ & $\begin{array}{l}\text { - Expansion of } \\
\text { eligible collateral; } \\
\text { - NCBs' supportive } \\
\text { measures against } \\
\text { individual problem } \\
\text { financial institution }\end{array}$ & $\begin{array}{l}\text { - Expansion of } \\
\text { eligible collateral }\end{array}$ \\
\hline & $\begin{array}{l}\text { - Outright purchase } \\
\text { of CP/ABCP and } \\
\text { CBs; } \\
\text { - Stock purchases } \\
\text { held by financial } \\
\text { institutions; } \\
\text { - Subordinated } \\
\text { loans to banks }\end{array}$ & $\begin{array}{l}\text { - AMLF, CPFF, and } \\
\text { MMIFF; } \\
\text { - Outright purchase } \\
\text { of Treasury } \\
\text { securities; } \\
\text { - TALF }\end{array}$ & $\begin{array}{l}\text { - Outright purchase } \\
\text { of covered bonds }\end{array}$ & $\begin{array}{l}\text { - Outright purchase } \\
\text { of gilts and CBs } \\
\text { (Asset Purchase } \\
\text { Facility) }\end{array}$ \\
\hline
\end{tabular}


Table 2. Policy Events

\begin{tabular}{|c|c|}
\hline Date & Changes in Policy Guidelines \\
\hline September 9, 1998 & Reduction of targeted $\mathrm{O} / \mathrm{N}$ rate $(0.5 \rightarrow 0.25 \%)$ \\
\hline November 13, 1998 & Introduction of new money market operations \\
\hline February 12, 1999 & Introduction of zero interest rate policy \\
\hline April 13, 1999 & $\begin{array}{l}\text { Governor's announcement of the commitment to zero interest rate } \\
\text { until deflationary concerns are dispelled }\end{array}$ \\
\hline October 13,1999 & Expansion of the range of money market operations \\
\hline August 11, 2000 & Termination of zero interest rate policy \\
\hline February 9, 2001 & $\begin{array}{l}\text { Reduction of ODR }(0.5 \rightarrow 0.375 \%) \text {, introduction of new way of } \\
\text { liquidity provision }\end{array}$ \\
\hline February 28, 2001 & $\begin{array}{l}\text { Reduction of targeted } \mathrm{O} / \mathrm{N} \text { rate }(0.25 \rightarrow 0.125 \%) \text { and } \mathrm{ODR} \\
(0.375 \rightarrow 0.25 \%)\end{array}$ \\
\hline $\begin{array}{l}\text { March 19, } 2001 \\
\text { (June 26, 2001) }\end{array}$ & $\begin{array}{l}\text { Decision to introduce quantitative monetary easing policy } \\
\text { (Publication of the "Outline of Basic Policies for Macroeconomic } \\
\text { Management and Structural Reform of the Japanese Economy") }\end{array}$ \\
\hline August 14, 2001 & Raise of the target $\mathrm{CAB}$ ( $5 \rightarrow 6$ trill. yen) \\
\hline (September 11, 2001) & Terror Attacks in US on September 11 \\
\hline September 18, 2001 & Raise of the target $\mathrm{CAB}(6 \rightarrow$ above 6 trill. yen) \\
\hline December 19, 2001 & Raise of the target $\mathrm{CAB}$ (above $6 \rightarrow 10-15$ trill. yen) \\
\hline September 18, 2002 & Introduction of stock purchasing plan \\
\hline (October 30, 2002) & (Publication of the "Program for Financial Revival") \\
\hline October 30, 2002 & Raise of the target $\mathrm{CAB}(10-15 \rightarrow 15-20$ trill. yen $)$ \\
\hline March 5, 2003 & $\begin{array}{l}\text { The target CAB adjustment }(15-20 \rightarrow 17-22 \text { trill. yen }) \text { effective from } \\
\text { April } 1 \text { due to the establishment of the Japan Post }\end{array}$ \\
\hline$($ Mar 20, 2003) & (Installation of Governor Fukui) \\
\hline April 30, 2003 & Raise of the target CAB (17-22 $\rightarrow 22-27$ trill. yen) \\
\hline May 20, 2003 & Raise of the target $\mathrm{CAB}(22-27 \rightarrow 27-30$ trill. yen $)$ \\
\hline \multirow[t]{2}{*}{ October 10, 2003} & $\begin{array}{l}\text { Increase in the upper limit of the target CAB }(27-30 \rightarrow 27-32 \text { trill. } \\
\text { yen) }\end{array}$ \\
\hline & Clarification of the commitment to maintaining the QEP \\
\hline January 20, 2004 & Raise of the target $\mathrm{CAB}(27-32 \rightarrow 30-35$ trill. yen $)$ \\
\hline Mar 9, 2006 & Termination of QEP \\
\hline
\end{tabular}


Figure 1. Total Assets for Major Central Banks

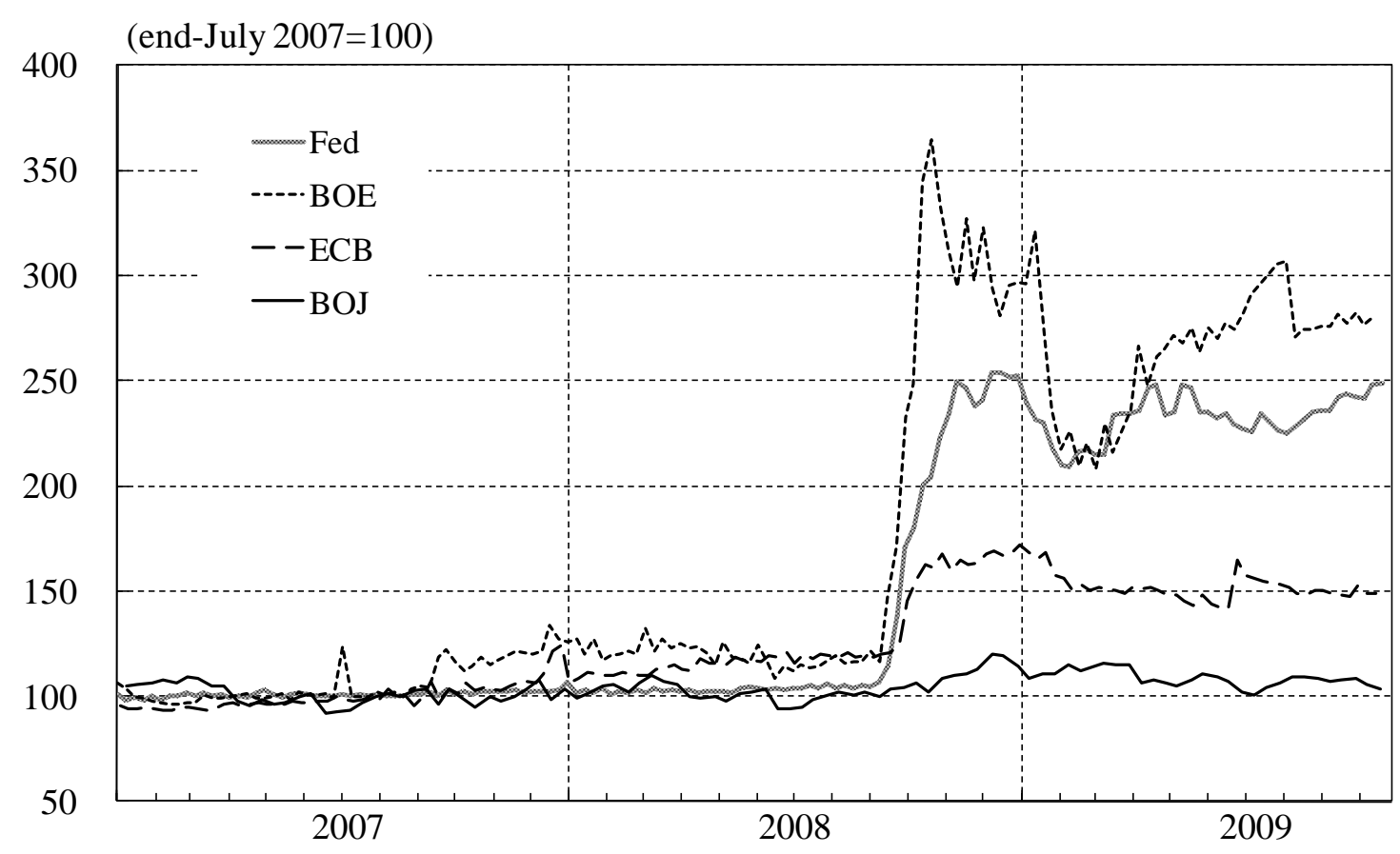

Sources: Board of Governors of the Federal Reserve System, "Factors Affecting Reserve Balances"; Bank of England, Monetary \& Financial Statistics; European Central Bank, Monthly Bulletin; Bank of Japan, Economic and Financial Statistics Monthly. 
Figure 2. Current Account Balances at the BOJ

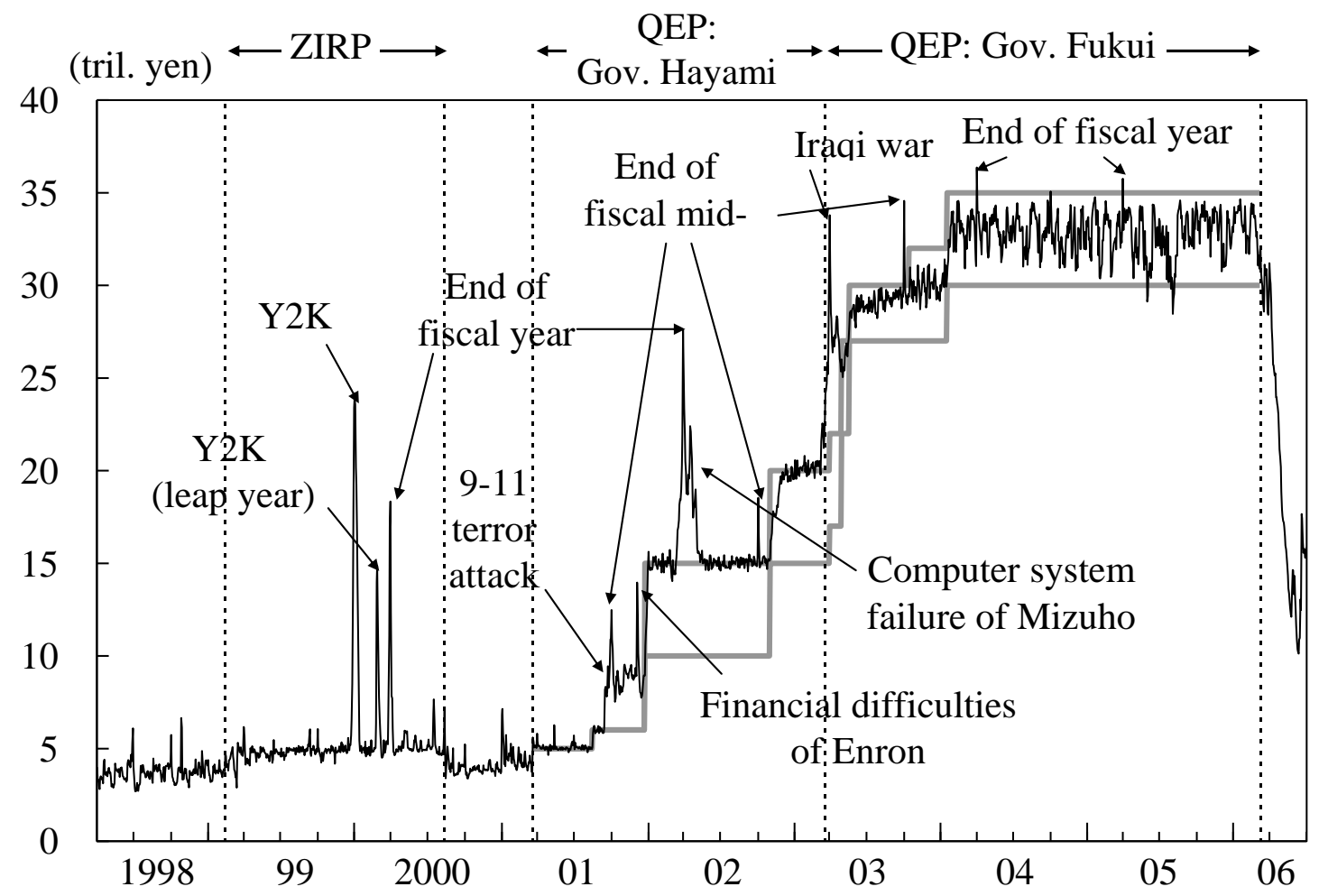

Note: Solid line indicates the outstanding amounts of the current account balances at the Bank of Japan, and shaded lines indicate the ceiling and floor of the target range of the current account balances.

Source: Bank of Japan, Economic and Financial Statistics Monthly. 
Figure 3. Core Inflation

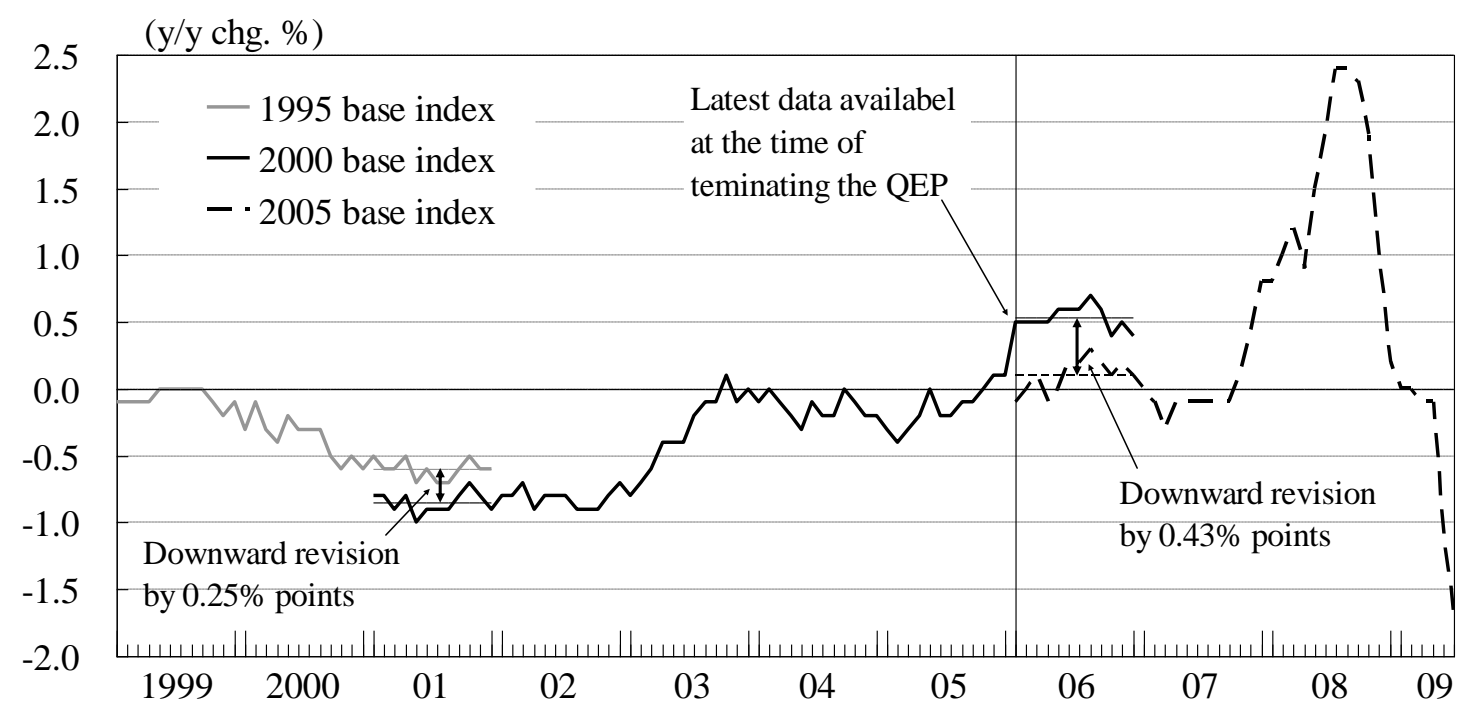

Note: Core inflation is an indicator that excludes the impacts of perishable food prices from the headline indicator.

Source: Ministry of Internal Affairs and Communications, Consumer Price Index.

Figure 4. Term Spreads

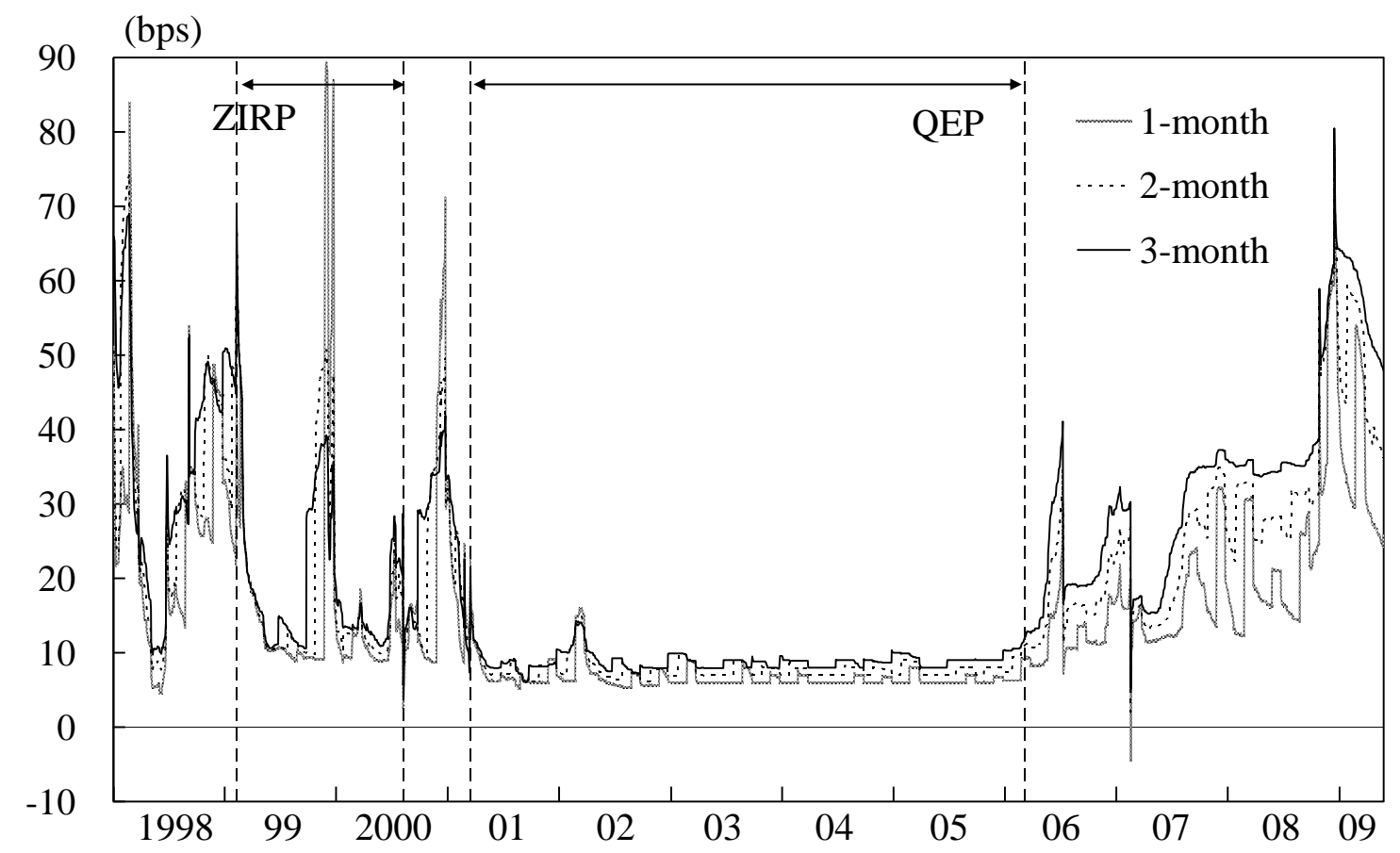

Note: Term spreads are defined as the differences between TIBORs for 1, 2, and 3-month contracts and overnight uncollateralized call rate.

Sources: Bloomberg; Bank of Japan, Economic and Financial Statistics Monthly. 
Figure 5. Maturity of Short-term Funds-supplying Operations

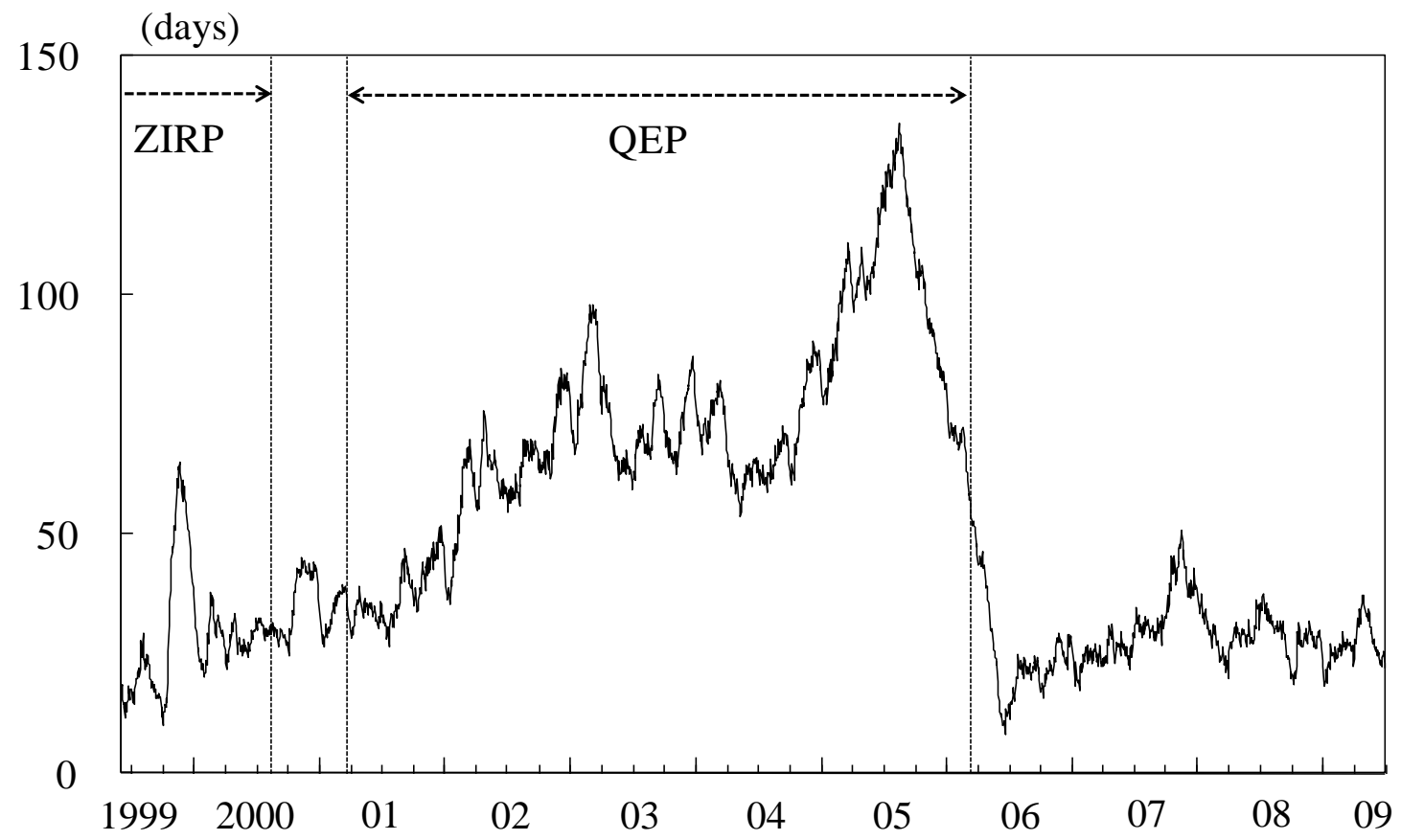

Notes: Figures are weighted average maturities of short-term funds-supplying operations offered during each quarter. The amounts of funds supplied are used as the weight. Short-term funds-supplying operations include: (1) funds-supplying operations against pooled collateral (bill-purchasing operations until June 2006), (2) purchase of Japanese Government Securities with repurchase agreements, and (3) purchases of $\mathrm{CP}$ with repurchase agreements.

Source: Bank of Japan, Economic and Financial Statistics Monthly. 
Figure 6. Credit Spreads

[1] Banks

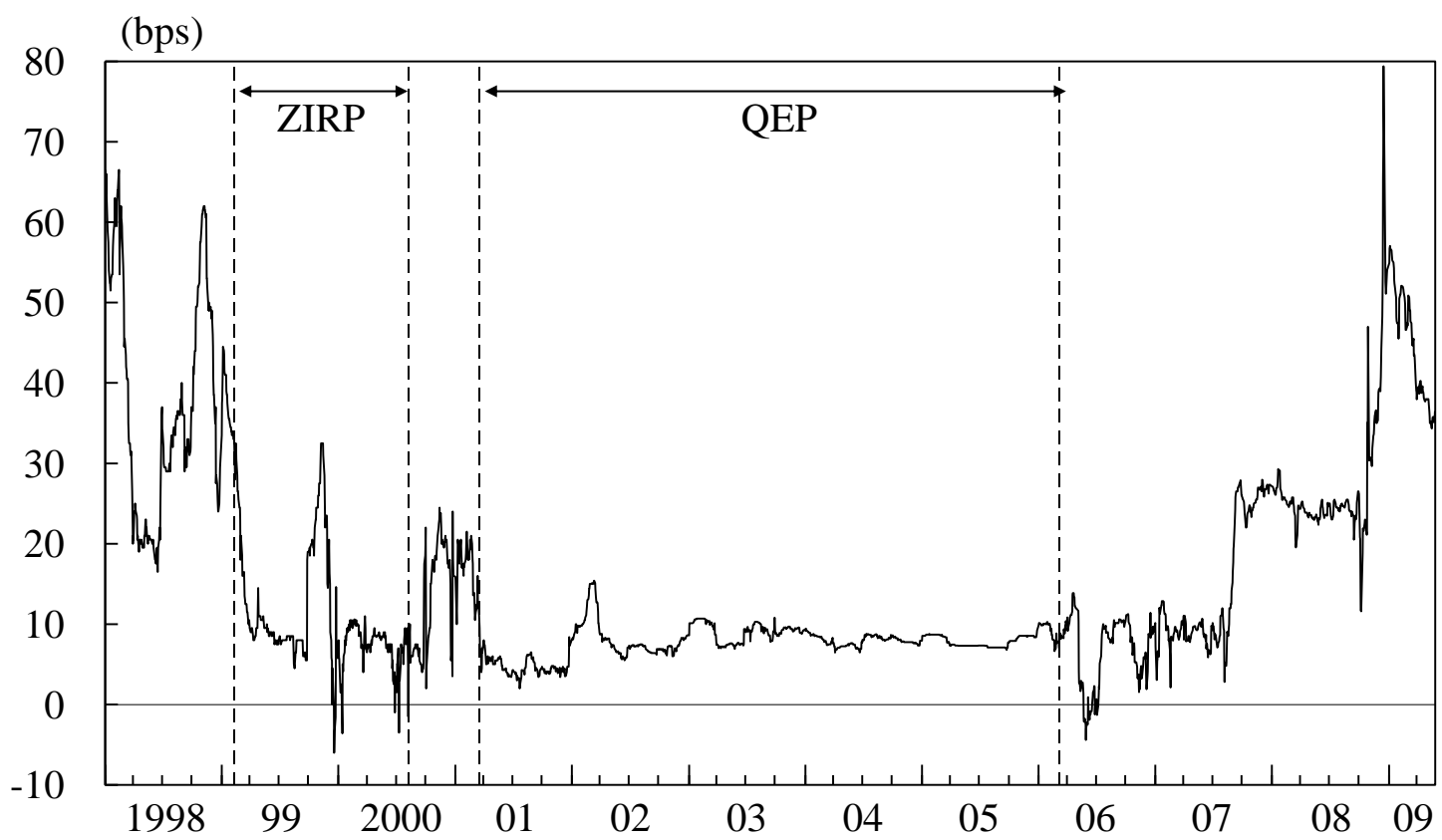

[2] Non-financial business

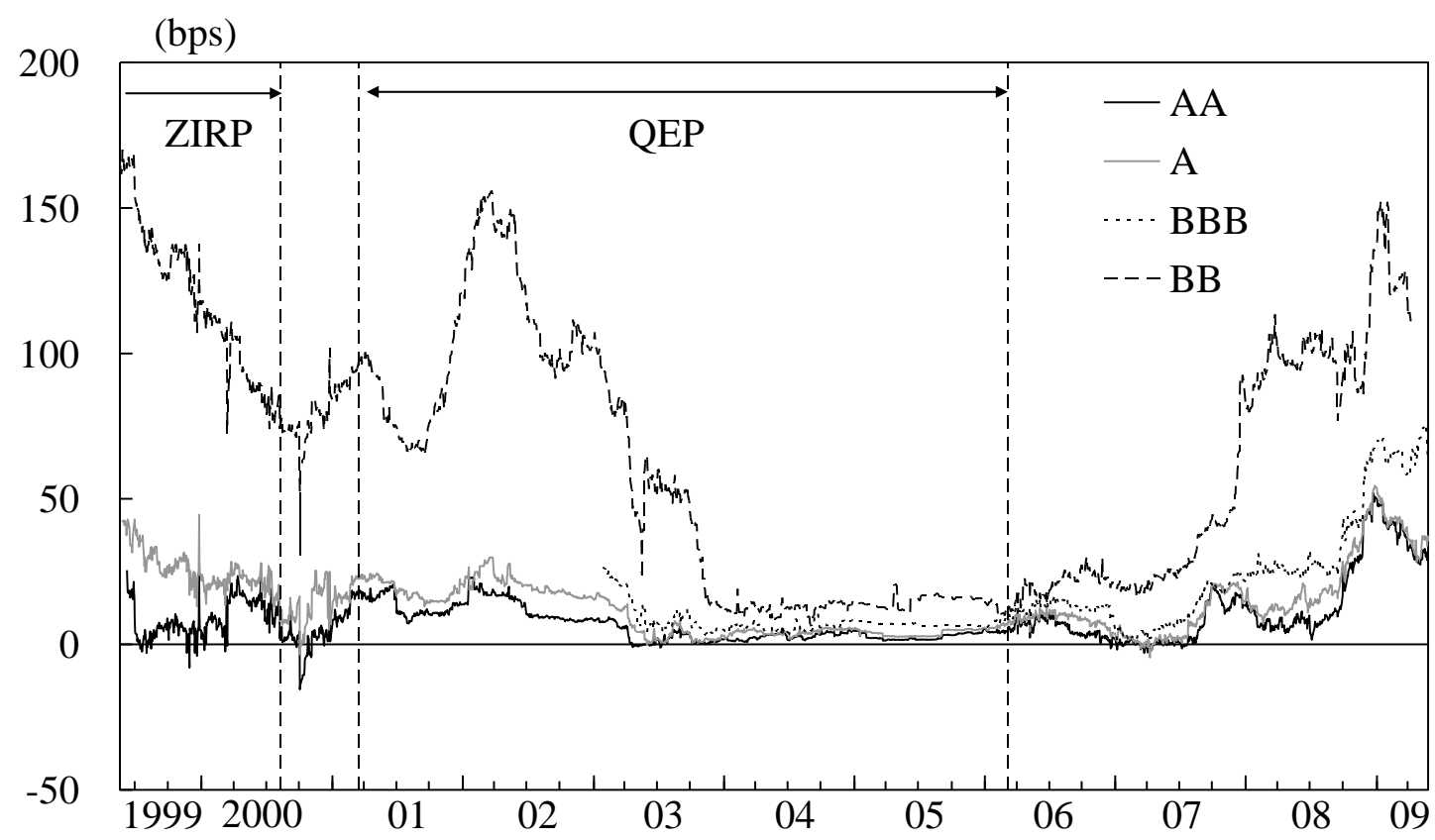

Note: Credit spreads are defined as the differences between credit product below and TB rates in three-month contracts.

Banks: CD new issue rate for 3-month

Non-financial business: Bloomberg Fair Market Value Index for companies with rating AA, $\mathrm{A}, \mathrm{BBB}$, and $\mathrm{BB}$

Sources: Bloomberg; Bank of Japan, Economic and Financial Statistics Monthly. 
Figure 7. CP Market

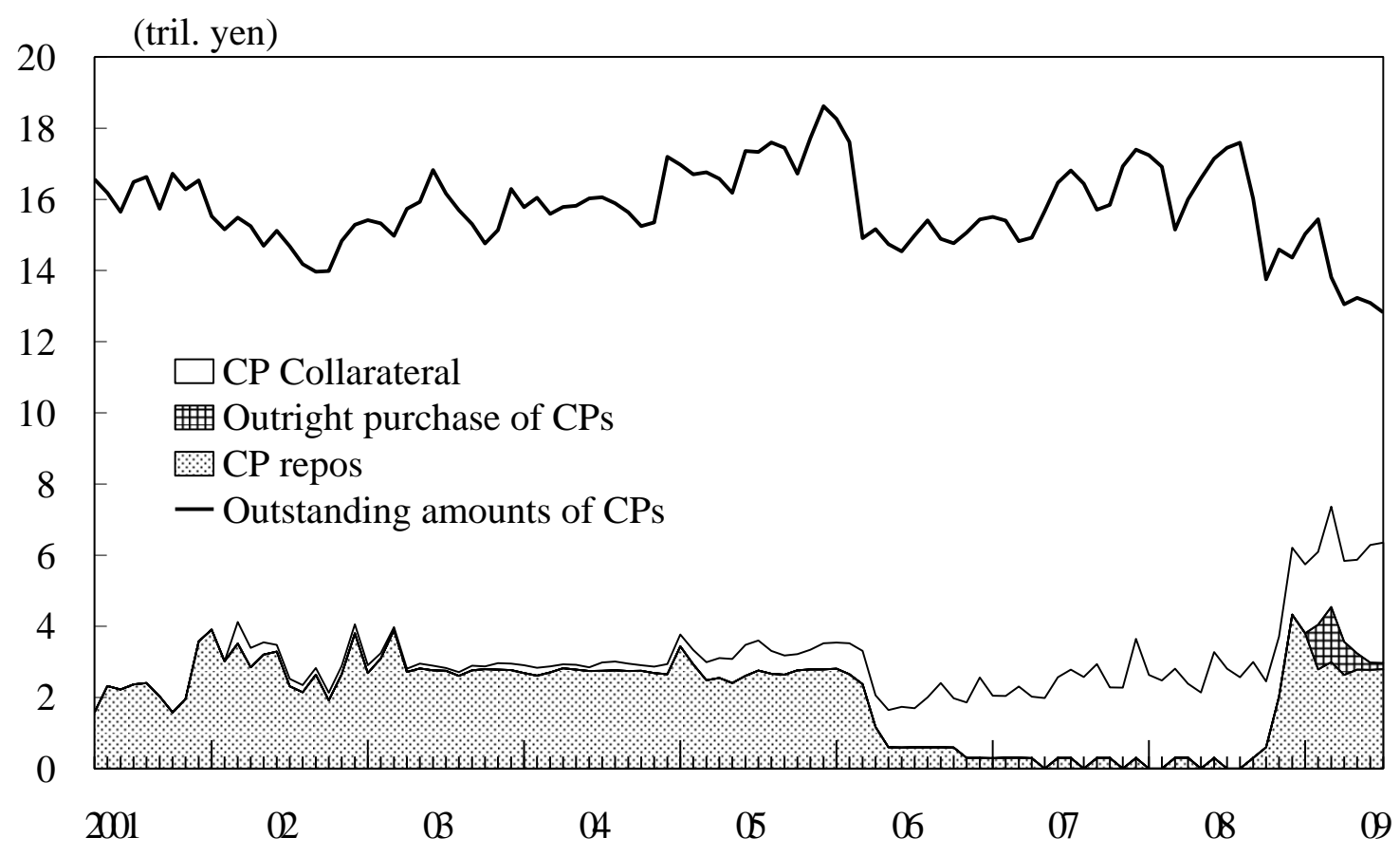

Source: Bank of Japan, Economic and Financial Statistics Monthly.

Figure 8. Outstanding Amounts of Uncollateralized Call Market

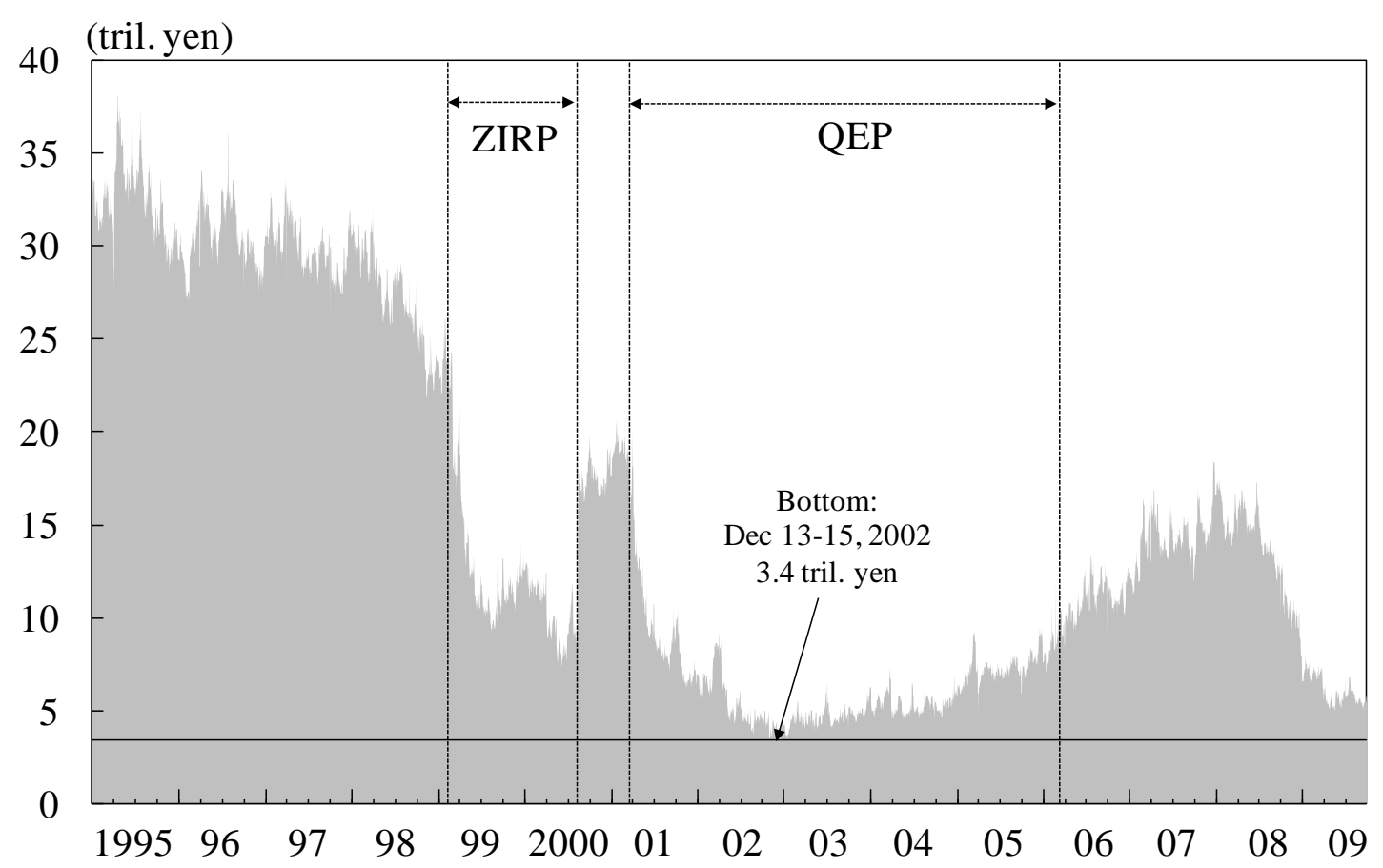

Source: Bank of Japan, Economic and Financial Statistics Monthly. 
Figure 9. Illustration of Unconventional Policy Measures

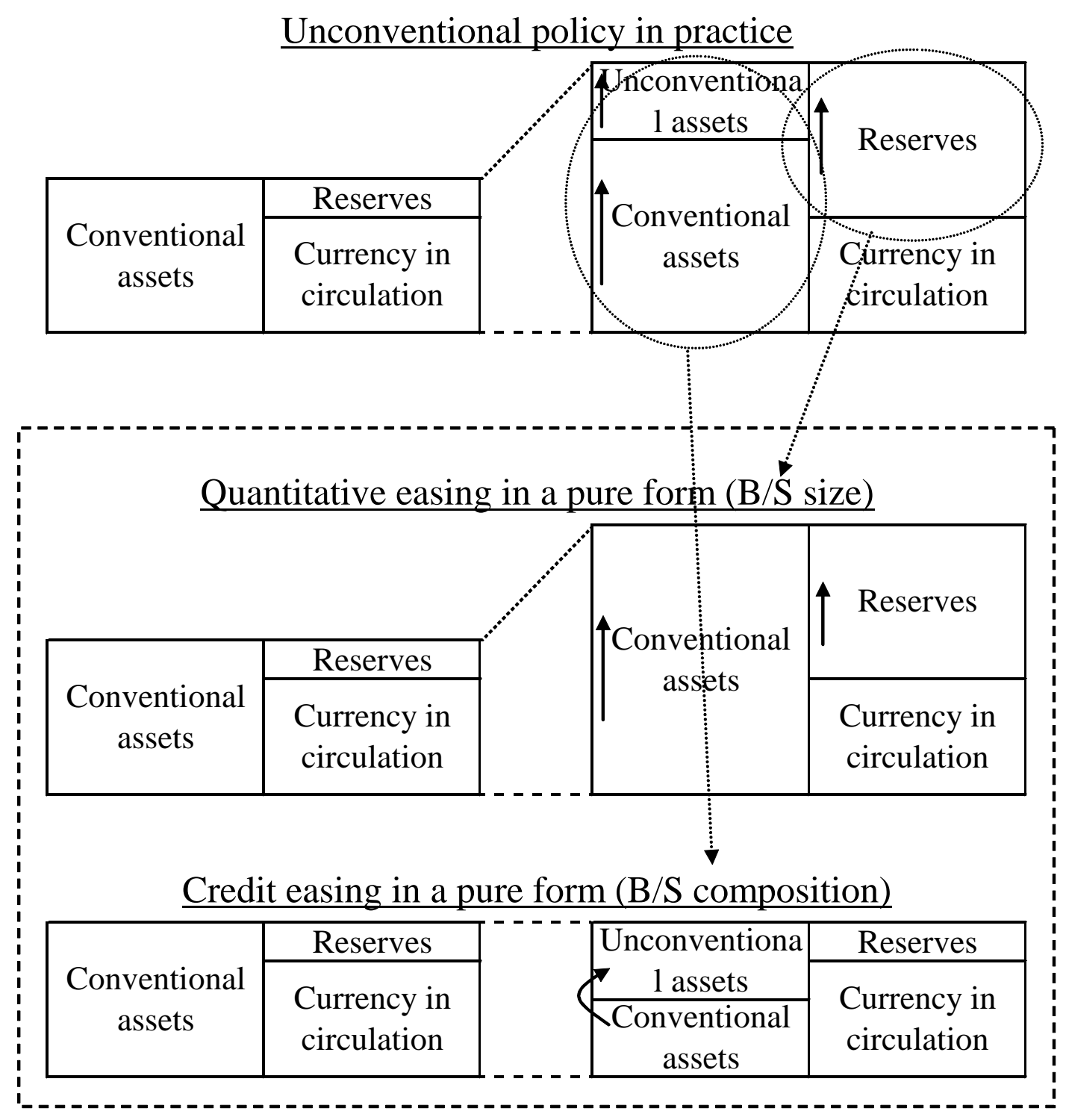


Figure 10. Central Bank Balance Sheet

[1] Japan
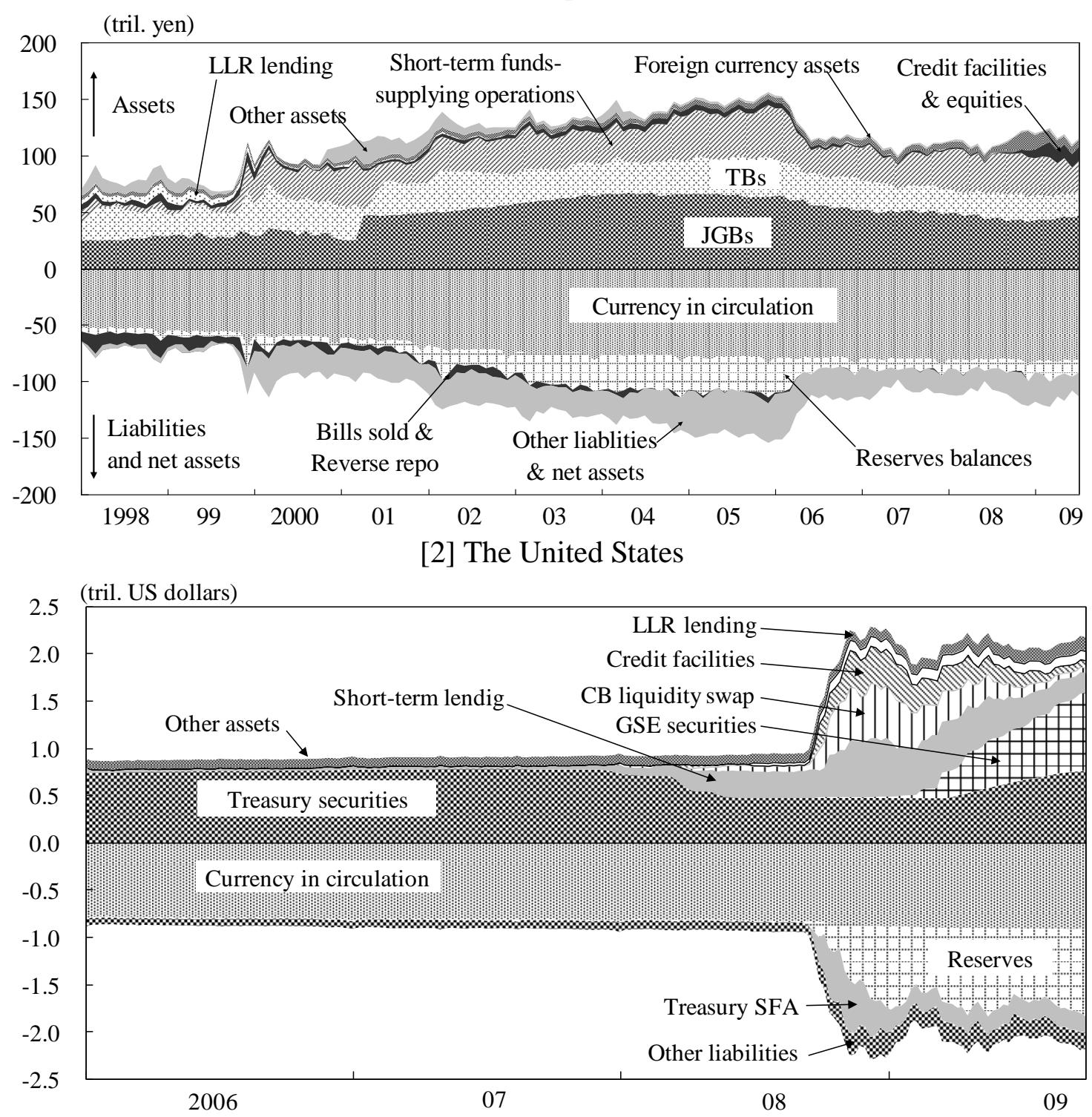

Notes: The details of asset components are as follows:

Bank of Japan: Short-term funds-supplying operations include funds-supplying operations against pooled collateral, purchase of JGBs and TBs with repurchase agreements, and complementary lending facility. Credit facilities and equities include: purchases of CPs with repurchase agreements, outright purchase of CPs, and purchase of equities held by commercial banks. LLR lending include: loans based on Article 38 of the BOJ Law, and those to the DIC.

Federal Reserve: Short-term lending include: short-term repos, primary credit, secondary credit, seasonal credit, and term auction credit. Credit facilities include: PDCF (primary dealer credit facility), TSLF (term securities lending facilities), AMLF (ABCP MMMF liquidity facility), CPFF (CP funding facility), MMIFF (money market investor funding facility), and TALF (term assetbacked loan facilities). LLR lending include: credit extended to AIG, and net portfolio holdings of Maiden Lane I, II, and III.

Sources:Board of Governors of the Federal Reserve System, "Factors Affecting Reserve Balances";

Bank of Japan, Economic and Financial Statistics Monthly. 
Figure 11. Structure of Financial Intermediations

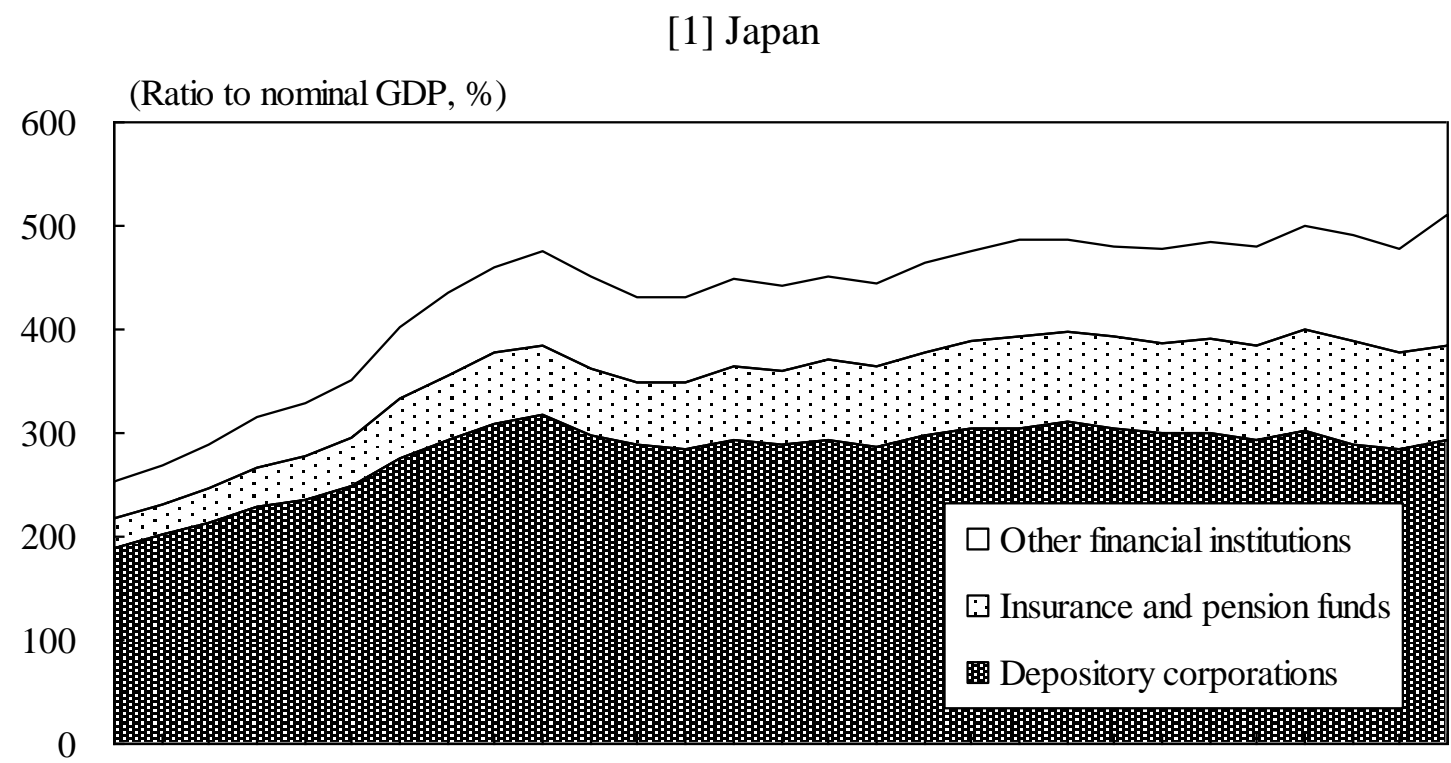

8081828384858687888990919293949596979899000102030405060708

\section{[2] The United States}

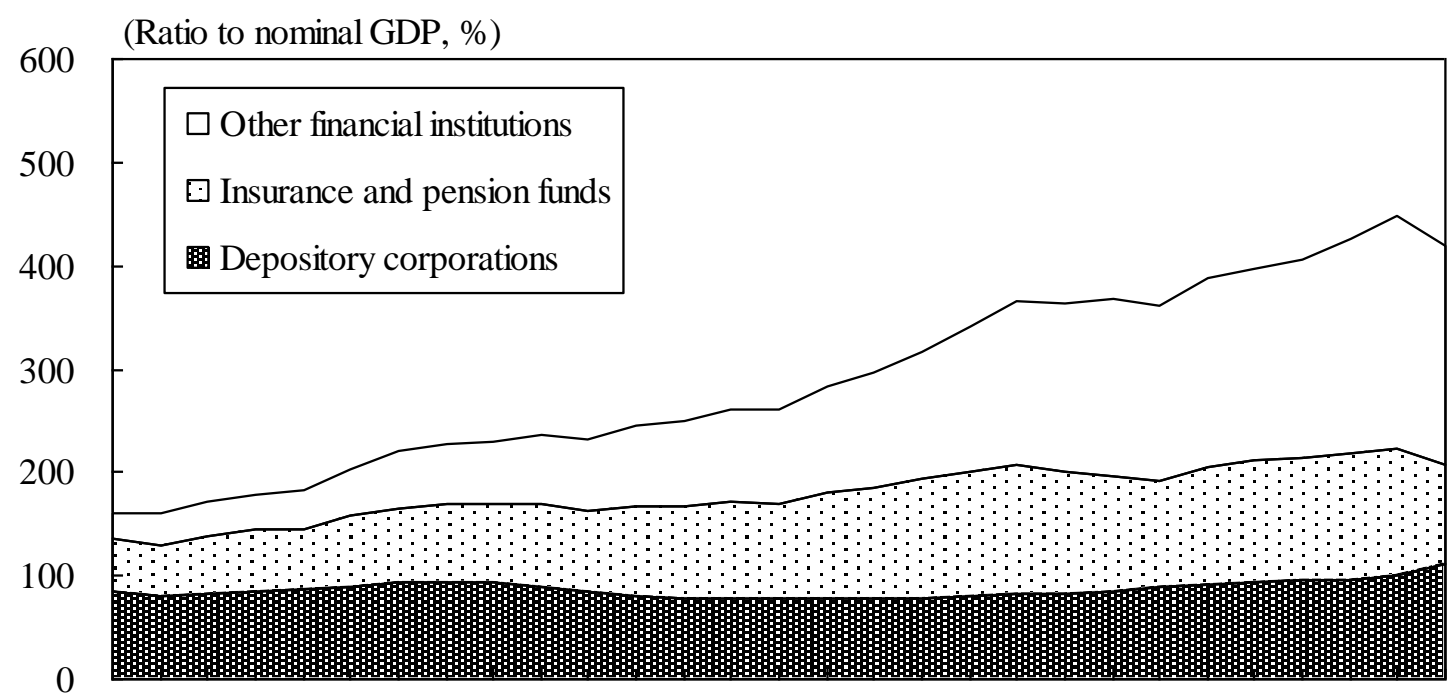

8081828384858687888990919293949596979899000102030405060708

Notes: Other financial institutions in Japan are comprised of securities investment trusts, nonbanks, and financial dealers and brokers. Those in the United States are the sum of investment trusts, financial dealers and brokers, nonbanks, and funding companies.

Sources: Cabinet Office, "National Accounts"; Bank of Japan, "Flow of Funds Accounts; "Bureau of Economic Analysis, "National Economic Accounts"; FRB, "Flow of Funds Accounts of the United States." 